\title{
THE DEVELOPMENT OF PRESCHOOLERS' COGNITIVE AND COMMUNICATIVE ACTIVITY IN THE PROCESS OF EDUCATIONAL AND RESEARCH ACTIVITIES IN NATURE
}

\author{
O DESENVOLVIMENTO DA ATIVIDADE COGNITIVA E COMUNICATIVA DE PRÉ- \\ ESCOLARES NO PROCESSO DE ATIVIDADES EDUCACIONAIS E DE PESQUISA \\ NA NATUREZA
}

\author{
EL DESARROLLO DE LA ACTIVIDAD COGNITIVA Y COMUNICATIVA DE LOS \\ PREESCOLARES EN EL PROCESO DE LAS ACTIVIDADES EDUCATIVAS Y DE \\ INVESTIGACIÓN EN LA NATURALEZA
}

\author{
Iryna KARAPUZOVA ${ }^{1}$ \\ Nataliia SULAIEVA ${ }^{2}$ \\ Nataliia MANZHELII ${ }^{3}$ \\ Oksana VASHAK ${ }^{4}$ \\ Tetiana FAZAN ${ }^{5}$
}

\begin{abstract}
Preschool education remains one of the strategic directions of state policy in the field of education. The current state of development of society in Ukraine opens considerable opportunities for updating the education content based on the principles of childcenteredness, humanization, and integration. The main aim of this article is to consider an essential issue of preschool education. As methods, analysis of productive activities (results of completed tasks), observation of children, and conversation with them are utilized. It is the organization of educational and research activities in nature as a means of developing preschool children's cognitive and communicative activity. Emphasis is put on their role in preschoolers' personal development, the feasibility of its implementation in preschool education. It is concluded that increasing the preschoolers' level of cognitive and communicative activity is possible using mnemonic tables and fairy tales about nature.
\end{abstract}

KEYWORDS: Research activities. Cognitive and communicative activity. Preschool children. Education. Mnemonic tables.

\footnotetext{
${ }^{1}$ Poltava V. G. Korolenko National Pedagogical University (PNPU), Poltava - Ukraine. Associate Professor of the Department of Preschool Education. Ph.D. in Pedagogics. ORCID: http://orcid.org/0000-0003-3552-080X. E-mail:weriti479@gmail.com

${ }^{2}$ Poltava V. G. Korolenko National Pedagogical University (PNPU), Poltava - Ukraine. Full Professor and Dean of the Faculty of Psychology and Pedagogy. Doctor of Pedagogical Sciences. ORCID: http://orcid.org/00000001-5066-8605. E-mail: Sula polt@ukr.net

${ }^{3}$ Poltava V. G. Korolenko National Pedagogical University (PNPU), Poltava - Ukraine. Associate Professor of the Department of Preschool Education. Ph.D. in Pedagogics. ORCID: https://orcid.org/0000-0003-1030-764X. E-mail: manzheliinata@gmail.com

${ }^{4}$ Poltava V. G. Korolenko National Pedagogical University (PNPU), Poltava - Ukraine. Associate Professor of the Department of Preschool Education. Ph.D. in Pedagogics. ORCID: http://orcid.org/0000-0002-7091-8242. Email: vashak1971.oa@gmail.com

${ }^{5}$ Poltava V. G. Korolenko National Pedagogical University (PNPU), Poltava - Ukraine. Assistant of the Department of Preschool Education. Ph.D. in Pedagogics. ORCID: https://orcid.org/0000-0001-9132-9394. Email: fazantp7@gmail.com
}

RPGE- Revista on line de Política e Gestão Educacional, Araraquara, v. 25, n. esp. 3, p. 1795-1809, Sep. 2021. e-ISSN: 1519-9029 
RESUMO: A educação pré-escolar continua sendo uma das direções estratégicas da política estadual no campo da educação. O atual estado de desenvolvimento da sociedade na Ucrânia abre oportunidades consideráveis para atualizar o conteúdo educacional com base nos princípios de centramento na criança, humanização e integração. O objetivo principal deste artigo é considerar uma questão essencial da educação pré-escolar. Como métodos, são utilizadas análises de atividades produtivas (resultados de tarefas concluídas), observação de crianças e conversação com elas. É a organização de atividades educacionais e de pesquisa na natureza como meio de desenvolver a atividade cognitiva e comunicativa de crianças em idade pré-escolar. A ênfase é colocada no seu papel no desenvolvimento pessoal dos préescolares, na viabilidade de sua implementação na educação pré-escolar. Conclui-se que aumentar o nível de atividade cognitiva e comunicativa dos pré-escolares é possível por meio do uso de tabelas mnemônicas e contos de fadas sobre a natureza.

PALAVRAS-CHAVE: Atividades de pesquisa. Atividade cognitiva e comunicativa. Préescolares. Educação. Tabelas mnemônicas.

RESUMEN: La educación preescolar sigue siendo una de las direcciones estratégicas de la política estatal en el campo de la educación. El estado actual de desarrollo de la sociedad en Ucrania abre oportunidades considerables para actualizar el contenido educativo basado en los principios del centrado en el niño, la humanización y la integración. El objetivo principal de este artículo es considerar un tema esencial de la educación preescolar. Como métodos, se utilizan el análisis de las actividades productivas (resultados de las tareas completadas), la observación de los niños y la conversación con ellos. Es la organización de actividades educativas y de investigación en la naturaleza como medio para desarrollar la actividad cognitiva y comunicativa de los niños en edad preescolar. Se enfatiza su papel en el desarrollo personal de los preescolares, la viabilidad de su implementación en la educación preescolar. Se concluye que es posible aumentar el nivel de actividad cognitiva y comunicativa de los niños en edad preescolar mediante el uso de tablas mnemotécnicas y cuentos de hadas sobre la naturaleza.

PALABRAS CLAVE: Actividades de investigación. Actividad cognitiva y comunicativa. Préescolares. Educación. Tablas mnemotécnicas.

\section{Introduction}

In modern conditions of education development, the relevant objectives become the following: to improve children's knowledge, to form appropriate skills, to develop their desire to experiment, to study events and phenomena, to enable independent research and acceptance of the laws of nature (DONCHENKO et al., 2020).

The Basic component of preschool education emphasizes that a preschooler is a subject of interaction with the natural environment (ZEBZEEVA, 1998). Given this, there is an urgent need to increase the status of educational and research activities as one of the appropriate means of forming the preschoolers' competence in the field of «Nature».

RPGE- Revista on line de Política e Gestão Educacional, Araraquara, v. 25, n. esp. 3, p. 1795-1809, Sep. 2021. e-ISSN: 1519-9029 DOI: https://doi.org/10.22633/rpge.v25iesp.3.15593 
Children's awareness of the relationship between nature and man and the various connections in nature plays an essential role in their personality development. Mastery of the means of practical interaction with the environment and peers ensures the child's personal growth (ZHAMARDIY et al., 2020).

The value of preschoolers' educational and research activities in nature is that children do not receive ready-made knowledge from the educator but acquire them in the course of practical activities while involving the hidden reserves of mental activity. Exploring objects of animate and inanimate nature, children develop observation, independence, initiative, curiosity, purposefulness, improve communication and work skills, learn to communicate with nature and get aesthetic pleasure from it, treat it responsibly, and learn to use natural resources etc. (KONONETS et al., 2020). In turn, it promotes the development the following moral qualities: sensitivity, mercy, kindness, and justice, and provide preschoolers' inner psychological comfort. Educational and research activities are a powerful means of children's cognitive and communicative activity and the formation of the foundations of a coherent worldview. Educational and research activities are the basis of empirical knowledge about the environment, a source of knowledge and development of cognitive interests and can last a lifetime. After all, the child's desire to explore the environment, to search for new information and impressions is biologically determined. Recently, there has been an increase in interest in educational and research activities in the preschool educational institutions, which indicates the relevance of this issue in preschool education (DONCHENKO et al., 2020).

\section{Materials and Methods}

The aim of the study is to highlight the role of educational and research activities in nature in the process of development of preschool children's cognitive and communicative activity. To achieve this goal, we chose the following research methods: analysis of productive activities (results of completed tasks), observation of children, and conversation with them. To determine the impact of children's educational and research activities in nature on the development of preschoolers' cognitive activity, we conducted an experimental study, which was carried out on the basis of Poltava preschool educational institution № 40 «Romashka» and Poltava preschool educational institution № 17 «School of Health». The participants of the study in the first preschool educational institution were children of the senior group «Metelyk» (experimental group («EG»), and in the second preschool educational institution were children of the senior group «Vyshenka» (control group («CG»). There were 
25 children in each group. Every stage of the experiment involved the implementation of planned tasks and the expected result.

\section{Results and Discussion}

In modern society, children live and develop in the age of informatization, which requires them not only to gain knowledge but also primarily the ability to acquire them independently, operate them, navigate freely in the environment, and solve problem situations creatively. For a child to become a harmonious personality, it is necessary to cultivate their interest in the surrounding reality. To do this, it is necessary to create a developmental environment that would promote the development of the children's cognitive and communicative activity.

In the Basic component of preschool education, in the educational line «A child in the sensory-cognitive dimension» it is emphasized that cognitive activity is characterized by the manifestation of the preschooler's interest in the environment, planning their cognitive activity and its implementation in practice (THE BASIC COMPONENT OF PRESCHOOL EDUCATION IN UKRAINE, 2012).

Cognitive activity motivates the child to cognitive actions, which accumulates the development of the following qualities: curiosity, observation, ingenuity, intelligence, awakening interest in the new, imagination, creativity, establishing positive motivation.

The problem of the development of cognitive activity was considered by various educators and psychologists. Thus, T. Tkachuk considered cognitive activity as a child's independent, proactive activity, aimed at learning about the surrounding reality (as a manifestation of curiosity) and due to the need to solve cognitive problems facing it in specific life situations (TKACHUK, 2002). S. Antonova defined cognitive activity as a process of acquiring research and research-related skills in the process of children and teachers' interaction, which aims to identify the essence of a problem relevant to all participants (ANTONOVA, 2009). S. Ladyvir characterized cognitive activity as a qualitative sign of a preschool child's actions, the property of the individual, the state of readiness for cognitive activity (LADYVIR, 2007). The scholar believed that cognitive activity was manifested in cognitive actions (LADYVIR, 2007). In turn, I. Kleshchova stated that cognitive activity was characterized by intrinsic motivation, special structural components (problem selection, organization, and analysis of data, hypothesis testing, formulation of conclusions), incomplete determinism of actions, a high degree of child's independence in the 
implementation individual stages or educational and research activities in general, obtaining objectively or subjectively a new result that enriches the child's system of knowledge (KLESHCHEVA, 2003).

It is essential to note that preschool children, especially older ones, can easily come into contact with adults and peers, they may be interested in participating in games, research activities; they are able to be sensitive, provide effective mutual assistance, and seek and accept help from an adult or other child. Preschoolers can actively interact with group members, solve common problems; they are able to calmly defend their point of view, while showing respect for others, for their interests. In our opinion, one of the most effective activities that can show the child's need for communication and cognition is educational and research activities in nature.

Today, despite extensive research in various fields of science, there is no single common definition of educational and research activities, but there are related concepts: search and research activities, search and cognitive activities, experimental and research activities, educational and search activities, educational and cognitive activities etc.

In our study, we have chosen the category «educational and research activities» because it aims at an activity approach that meets the preschooler's needs in cognition and promotes the development of their cognitive activity in the process of conducting experiments.

Logical-semantic analysis of the definition «educational and research activities» allowed a comprehensive study of this scientific category. Thus, H. Likhodeeva emphasizes that educational and research activities are activities organized by the teacher using various forms and didactic techniques, which are dominated by independent conscious use of methods of scientific knowledge and as a result, children actively acquire knowledge, develop their research skills and abilities. The result of children's educational and research activities is an intellectual product associated with the establishment of truth as a result of the research process (LIKHODIEIEVA, 2009). According to N. Nedatatok, educational and research activities are characterized by the creative orientation of the content of mental operations, as well as pedagogical management of the process of formation of educational and research skills, which are most successful as children are learning to predict the result, formulate goals and hypotheses, seek independent ways to solve goals and substantiate the correctness of the decision (NEDATATOK, 2000).

In turn, V. Zebzieieva notes that in the course of experiments with objects of nature, there is an influence on the formation of a young researcher's personal traits. There is an 
initiative in making suggestions, independence in determining the sequence of tasks, cooperation with other children and adults, use of auxiliary sources, distribution of the time. The preschooler learns to work in a team, to show their own organizational skills, to feel a sense of duty and responsibility, to help other children, to consider their opinions, and to respect them as individuals. It contributes not only to the child's social comfort but at the same time, during educational and research activities in nature there is a moral education (ZEBZEEVA, 1998).

Analysis of scientific literature allows us to determine that educational and research activities in preschool educational institutions are a form of an acquaintance of preschoolers with nature, which is based on the search, study, and systematization on a scientific basis of subjectively new knowledge acquired by children in specially organized conditions and contribute to the development of their cognitive activity.

Educational and research activities in nature successfully combine the sensitivity of the senses and activities that are the basis of the child's sensory development. Exploring objects of nature with the help of various analyzers, preschoolers learn to distinguish the properties of objects. At the same time, there is a formation of sensory standards (LIUTA, 2014).

Considering children's educational and research activities in nature, we should pay attention to its structure, which includes the stages of experiments, the activities of educators and children at each stage and the expected results.

The first stage of educational and research activities is preparation for research activities in nature. It should be aimed at identifying the level of children's knowledge about the studied objects and natural phenomena, as well as creating an atmosphere of interest. It is facilitated by appropriate questions and an interesting tale. The educator's activity at this stage is to update the problem situation, create the necessary conditions for the experiment (preparation of the necessary equipment, creation of a map-scheme etc.), form children's motivation for research activities, instruction on safety during implementation this type of activity. At the same time, preschoolers' activity is to get aware in the problem and prepare a workplace. The expected result is the emergence of children's interest, cognitive interest, and desire to participate in the experiment, the creation of optimal conditions for the experiment (KARAPUZOVA, 2016).

The next, second stage is the beginning of the experiment. It begins with the children making assumptions, the correctness or falsity of which will be confirmed during the experiment. The experiment should then be discussed. All conditions during the discussion 
must be the same, except for one. It is necessary to ensure the purity of the experiment. At this stage, the educator's activities include discussing the problem with preschoolers, bringing them to the goal of the experiment, putting forward working hypotheses, helping children formulate hypotheses, discussing with children the algorithm for the experiment, compiling the algorithm, bringing children to the algorithm actions, comprehension of the content of the map-scheme of experiment, making adjustments as necessary, prevention of deviations from the set goal. The preschoolers' activity is to formulate the purpose of the experiment, put forward hypotheses, compile an algorithm for educational and research activities, understanding the content of the map-scheme of the experiment, clarifying the problem, discussing new hypotheses that arise as needed. The expected result is to determine the purpose of the experiment, to put forward several working hypotheses, to compile an algorithm for conducting the experiment, to prevent deviations from the set goal (KARAPUZOVA, 2016).

The third stage is the direct course of the experiment and the subsequent exchange of views. At this stage, the educator provides assistance to children in organizing practical activities, together with children performs practical actions as needed, and monitors compliance with safety rules when children conduct an experiment. The preschoolers' activities during the experiment include making a new hypothesis with its subsequent implementation in case of non-confirmation of the original hypothesis, selection of the necessary tools, and formulation of conclusions. The expected result is a direct experiment (KARAPUZOVA, 2016).

The fourth stage is the final one. The results of the experiment are discussed; certain conclusions are made. The assumptions made by children are confirmed or refuted. At the final stage, the educator's activity is to summarize and evaluate the results of work. The preschoolers' activity at this stage of the experiment involves self-assessment and rethinking the problem from a new perspective. The expected result at the final stage is the confirmation or refutation of the hypothesis, the assimilation of certain knowledge by children (KARAPUZOVA, 2016).

Analysis of the educators' experience on the use of preschoolers' educational and research activities has shown that for the development of cognitive activity during these activities, different tools are used. However, in our opinion, not enough attention is paid to mnemonic techniques and fairy tales about nature.

The mnemonic technique (from Greek - the art of remembering) is a system of methods and techniques that ensure successful memorization, storage and reproduction of 
information, knowledge about the features of nature and the world, effective memorization of the tale plot, as well as contribute to the speech development (DONCHENKO et al., 2020). This educational technology, which helps the child to comfortably and easily acquire knowledge using the natural mechanisms of the brain, allows to fully control the process of remembering, storing, and reproducing information. One of the methods of mnemonics is a mnemonic table.

A mnemonic table is a diagram in which certain information is embedded sequentially. Mastering the techniques of working with mnemonic table significantly reduces learning time and at the same time promotes the development of memory, ability to analyze, select parts, combine into pairs, groups, systematize, development of logic, figurative thinking, ability to compose stories, solving didactic, educational tasks, attention training. The content of the mnemonic table is a graphic or partially graphic depiction of fairy tale characters, natural phenomena, certain actions etc., thanks to the selection of the main semantic lines of the tale. It is essential to transfer the conditional-visual scheme, which must be depicted so that the drawing is clear to children (DONCHENKO et al., 2020).

To increase the level of cognitive activity, in our opinion, together with a mnemonic table, it is advisable to use a fairy tale about nature, created on a scientific basis. With its help, the preschooler can form the logical meaning of the events that precede or contribute to the emergence of a phenomenon. If in this case, the mnemonic table allows the child to understand the sequence of the phenomenon under study, the fairy tale, in turn, acquaints the preschooler with the events that cause a phenomenon, as well as introduces the child to the consequences. An interesting plot of the fairy tale stimulates the development of the preschooler's cognitive mental processes, allows them to enrich knowledge in the field of «Nature». As it is known, the language of fairy tales is simple and accessible to children, it describes natural phenomena difficult to perceive at a level accessible to children, helps to form preschoolers' primary ideas about the world of nature, forms a respectful attitude to the world of animate and inanimate nature. A fairy tale is an effective means of educating children in natural behavior, which accumulates the child's need for knowledge and promotes the development of their cognitive and communicative activity.

At the first stage of the study, we conducted an ascertaining experiment, the purpose of which was to determine the indicators and levels of development of preschoolers' cognitive activity in the field of «A child in the natural environment». To achieve this goal, we chose the following research methods: analysis of productive activities (results of completed tasks), observation of children, and conversation with them.

RPGE- Revista on line de Política e Gestão Educacional, Araraquara, v. 25, n. esp. 3, p. 1795-1809, Sep. 2021. e-ISSN: 1519-9029 DOI: https://doi.org/10.22633/rpge.v25iesp.3.15593 
The analysis of the obtained results made it possible to determine three levels of development of children's cognitive and communicative activity in the field of «A child in the natural environment». They are the high, the average and the low levels.

The high level of formation of preschool children's natural knowledge is the following: knowledge is generalized, systemic, the child confidently answers questions, considers objects (phenomena) holistically, is able to generalize, classify, identify objective relationships within a group of subjects or phenomena, has a wealth of nonverbal means, can explain the observed in nature patterns, express their views and attitudes to objects of nature.

The average level of formation of preschool children's natural knowledge is the following: a certain amount of factual knowledge about the needs of plants and animals is diagnosed, the system and generalization of knowledge are poorly traced. The child can establish some connections and dependencies in nature, however, cannot always explain them, is able to analyze objects and phenomena of nature, and highlights the essential in them, using the help of the educator. The preschooler shows low activity in communication, monologue and dialogic speech is not sufficiently formed.

The low level of formation of preschool children's natural knowledge is the following: the child has a small volume, inaccurate knowledge, answers uncertainly, thinking for a long time, with a hint or leading questions, gives an incomplete answer, listing the individual features of natural objects, cannot identify the essential in the object (phenomenon), is not able to establish connections and dependencies, has unformed motives for communication with adults and peers, has no initiative in dialogue, has the same type of phrase construction and lack of creative storytelling.

The results of the ascertaining study suggest that more than half of preschoolers in the experimental group «Metelyk» $(52 \%)$ had the low level of cognitive and communicative activity in the field of «A child in the natural environment», $32 \%$ of children had the average level, and $16 \%$ of children had the high level of cognitive activity development. The results obtained during the ascertaining stage of the study are presented in table 1.

Table 1 - Levels of preschoolers' cognitive and communicative activity development at the ascertaining stage of experimental research

\begin{tabular}{|c|c|c|c|c|c|c|c|}
\hline \multirow{2}{*}{ Group title } & \multirow{2}{*}{$\begin{array}{c}\text { Total amount of } \\
\text { children }\end{array}$} & \multicolumn{2}{|c|}{ High level } & \multicolumn{2}{c|}{ Average level } & \multicolumn{2}{c|}{ Low level } \\
\cline { 3 - 8 } & & Amount & $\%$ & Amount & $\%$ & Amount & $\%$ \\
\hline$\ll$ Metelyk» $(\mathrm{EG})$ & 25 & 5 & $20 \%$ & 7 & $28 \%$ & 13 & $52 \%$ \\
\hline$\ll$ Vyshenka» $(\mathrm{CG})$ & 25 & 4 & $16 \%$ & 6 & $24 \%$ & 15 & $60 \%$ \\
\hline
\end{tabular}

Source: Prepared by the authors

RPGE- Revista on line de Política e Gestão Educacional, Araraquara, v. 25, n. esp. 3, p. 1795-1809, Sep. 2021. e-ISSN: 1519-9029 
The formative stage of the experiment involved direct educational and research activities of children in nature. A series of classes on educational and research activities were organized for the experimental group. They took place in the form of a fairy tale. During the classes, children conducted experiments «Paper Lilies», «Multicolored Flowers», «Mysterious Traces», «A Rainbow» based on the fairy tale plot with the usage of mnemonic tables. We developed technological cards for educators for each of these experiments. These cards indicated the topic, purpose, conditions of the experiment, didactic materials required for this experiment, described in detail the stages and the actions of the educator and children at each stage. In the control group the usual classes were conducted using elementary experiments.

Surveys of the educators of the experimental group on the use of technological cards of experiments showed that it was easier for educators to prepare for the classes, monitor the children's actions at each stage of the experiment, as well as quickly navigate their actions during the class. Analyzing the results of the formative stage of the experimental study, we observed the dynamics of the increase in the average level, which is shown in table 2.

Table 2 - Levels of development of preschoolers' cognitive and communicative activity at the formative stage of experimental research

\begin{tabular}{|c|c|c|c|c|c|c|c|}
\hline \multirow{2}{*}{ Group title } & \multirow{2}{*}{$\begin{array}{c}\text { Total amount of } \\
\text { children }\end{array}$} & \multicolumn{2}{|c|}{ High level } & \multicolumn{2}{c|}{ Average level } & \multicolumn{2}{c|}{ Low level } \\
\cline { 3 - 8 } & & Amount & $\mathbf{\%}$ & Amount & $\%$ & Amount & $\%$ \\
\hline$\ll$ Metelyk» $(\mathrm{EG})$ & 25 & 7 & $28 \%$ & 10 & $40 \%$ & 8 & $32 \%$ \\
\hline$\ll$ Vyshenka $(\mathrm{CG})$ & 25 & 6 & $24 \%$ & 8 & $32 \%$ & 11 & $44 \%$ \\
\hline
\end{tabular}

Source: Prepared by the authors

It should be emphasized that the fairy tale with experiments, used in educational and research activities, promotes the development of preschoolers' cognitive activity in the field of «A child in the natural environment», the formation of children with the low and the average levels of new knowledge, skills and consolidation of already acquired knowledge and skills among children who had a high level of cognitive development.

After the first class, we decided to enhance the effectiveness of research activities using mnemonic tables. The introduction of this method has successfully realized our objective of increasing the level of preschoolers' cognitive activity, during the formation of causal relationships in the course of experiments. In this regard, we have selected fairy tales about nature with mnemonic tables for experiments and technological cards, which contain guidelines for educators on the management of preschoolers' educational and research activities.

RPGE- Revista on line de Política e Gestão Educacional, Araraquara, v. 25, n. esp. 3, p. 1795-1809, Sep. 2021. e-ISSN: 1519-9029 DOI: https://doi.org/10.22633/rpge.v25iesp.3.15593 
After conducting research activities and using a set of mnemonic tables for children and technology cards for educators, to test the effectiveness of the developed and implemented methodology, we re-diagnosed the level of development of preschool children' cognitive activity of in the field of «A child in the natural environment». The results obtained during the formative experiment, we presented in table 3.

Table 3. Levels of development of preschoolers' cognitive and communicative activity at the formative stage of the experimental study

\begin{tabular}{|c|c|c|c|c|c|c|c|}
\hline \multirow{2}{*}{ Group title } & \multirow{2}{*}{$\begin{array}{c}\text { Total amount } \\
\text { of children }\end{array}$} & \multicolumn{2}{|c|}{ High level } & \multicolumn{2}{c|}{ Average level } & \multicolumn{2}{c|}{ Low level } \\
\cline { 3 - 8 } & Amount & $\%$ & Amount & $\%$ & Amount & $\%$ \\
\hline$«$ Metelyk» $(\mathrm{EG})$ & 25 & 9 & $36 \%$ & 11 & $44 \%$ & 5 & $20 \%$ \\
\hline$« V y$ shenka» $(\mathrm{CG})$ & 25 & 8 & $32 \%$ & 9 & $36 \%$ & 8 & $32 \%$ \\
\hline
\end{tabular}

Source: Prepared by the authors

Analysis of the study data in the experimental group showed that the number of children with the low level of awareness in the field of «A child in the natural environment» after the experiment decreased almost twice from $52 \%$ to $20 \% .44 \%$ of children showed the average level (there were $28 \%$ ), but the essence of the changes was not so much in quantitative as in qualitative changes, as some children whose level corresponded to the average had a high level, and children whose level corresponded to low, entered the average one. $36 \%$ of preschoolers had the high level of academic achievement compared to the previous data. The results almost doubled. Based on these data, it can be stated that the method developed by the authors allowed to increase the level of preschoolers' cognitive and communicative activity qualitatively and quantitatively.

Figure 1 - Dynamics of changes in the level of children's cognitive and communicative activity in the experimental and control groups before and after the experimental study

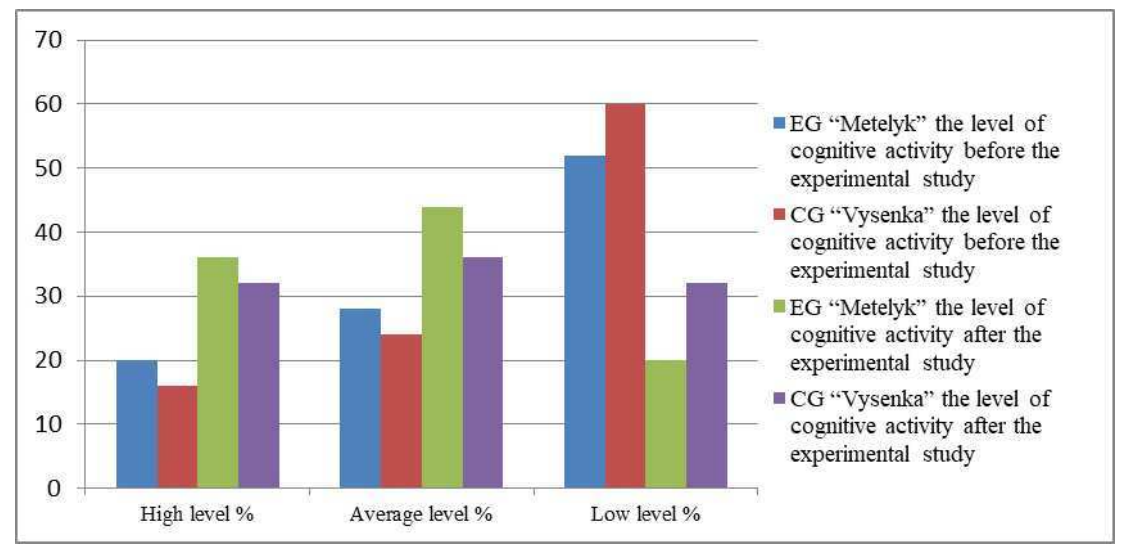

Source: Prepared by the authors

RPGE- Revista on line de Política e Gestão Educacional, Araraquara, v. 25, n. esp. 3, p. 1795-1809, Sep. 2021. e-ISSN: 1519-9029 
According to Fig. 1, we can state the positive results of the work, namely the high efficiency of the use of preschoolers' educational and research activities in the process of their cognitive activity development during acquaintance with natural objects. The introduction of fairy tales for better perception of information by preschoolers during experiments was effective. Mnemonic tables allowed to highlight each stage of the experiment and contributed to a better perception of new information.

In the course of the experimental study, we also conducted a survey among educators. They positively assessed of the use of mnemonic tables and technological cards for the organization of educational and research activities in the conditions of a preschool educational institution. According to educators, such tools simplified the preparation stage for the implementation of educational and research activities and helped structure the stages of experiments.

\section{Conclusions}

Children's educational and research activities in the process of acquainting them with the objects of nature, using a fairy tale with experiments and mnemonic tables, increase the level of development of preschoolers' cognitive and communicative activity in the field of «A child in the natural environment» and is effective. Children learn to establish general patterns and, on their basis, to create causal chains that help them to successfully use the acquired knowledge in a new situation, get the opportunity to satisfy their inherent curiosity, develop research skills and abilities. Based on this, it is natural to believe that such skills contribute to the independent cognitive activity of children, the development of elements of critical independent thinking, which is the driving force in the development of preschool children's cognitive activity; formation of communicative competence, namely the ability to express their desires, intentions, assumptions, as well as to explain their actions and their content.

\section{REFERENCES}

ANTONOVA, S. YU. Management of educational and research activities of high school students in modern socio-cultural conditions: author. Extended abstract of $\mathrm{PhD}$ thesis. Biysk, 2009, 20 p.

DONCHENKO, V. I.; ZHAMARDIY, V. O.; SHKOLA, O. M.; KABATSKA, O. V.; FOMENKO, V. H. Health-saving Competencies in Physical Education of Students. Wiadomości Lekarskie, Tom LXXIII, 1, 145-150. 2020. 
GRIBAN, G.; PRONTENKO, K.; ZHAMARDIY, V.; TKACHENKO, P.; KRUK, M.; KOSTYUK, Y.; ZHUKOVSKYI, Y. Professional Stages of a Physical Education Teacher as Determined Using Fitness Technologies. Journal of Physical Education and Sport, 18 (2), 565-569. 2018.

KARAPUZOVA, I. V. Children's experimentation: realities and prospects. Pedagogical sciences: theory, history, innovative technologies: academic journal / Eds. A. A. Sbruiev. Sumy, publishing house of Sumy State Pedagogical University named after A. S. Makarenko, 9 (63), 39-50. 2016.

KLESHCHEVA, I. V. Organization of educational and research activities of students in the study of mathematics. Extended abstract of PhD thesis. SPb, 2003, $20 \mathrm{p}$.

KONONETS, N.; GRYNOVA, M.; ZHAMARDIY, V.; MAMON, O.; LIULKA, H.

Problems of Implementation of The System of Resource-Based Learning of Future Teachers of Physical Culture. International Journal of Applied Exercise Physiology, 9 (12), 50-60. 2020 .

KORNOSENKO, O.; DENYSOVETS, T.; DANYSKO, O.; SYNYTSYA, S.; VOLOSHKO, L.; ZHAMARDIY, V.; DONCHENKO, V.; SHKOLA, O.; PRYSTYNSKYI, V.; OTRAVENKO, O. System of Preparation of Future Fitness Coaches' for Health-Improving Activity in the Conditions of Rehabilitation Establishments. International Journal of Applied Exercise Physiology, 9 (8), 33-41. 2020.

LADYVIR, S. O. Developmental opportunities of the research method of teaching preschoolers. Current problems of psychology. Psychology of preschool development. Collection of scientific articles. Kyiv, IV(IV), 96-97. 2007.

LADYVIR, S. O.; STADNYK, H. A. Development of children's cognitive activity in the process of their communication with parents. Psychology. Kyiv, 34, 53-59. 1990.

LIKHODIEIEVA, H. V. Formation of educational and research skills of students in the process of learning the elements of stochastics. Kyiv, 2009, 20 p.

LIUTA, T. O. Formation of intellectual and creative skills of junior schoolchildren by means of educational and research activities. Educational research activities of children: experience of organization, didactic developments, features of formation of educational and research skills: Proceeding of the All-Ukrainian Scientific and Practical Conference.

Kirovohrad, April 9-10, 2014. Kirovohrad, 101-105.

NEDATATOK, N. H. Formation of educational and research skills of high school students. Extended abstract of PhD thesis. Kharkiv, 2000, 20 p.

SHKOLA, O.; GRIBAN, G.; PRONTENKO, K.; FOMENKO, O.; ZHAMARDIY, V.; BONDARENKO, V.; BEZPALIY, S.; ANDREYCHUK, V.; TKACHENKO, P.; BLOSHCHYNSKY, I.; ZHUKOVSKYI, Y.; NOVITSKA, I. Formation of Valuable Orientations in Youth during Physical Training. International Journal of Applied Exercise Physiology, 8 (3.1), 264-272. 2019. 
SHKOLA, O.; ZHAMARDIY, V.; SAIENKO, V.; TOLCHIEVA, H.;

POLULIASHCHENKO, I. The Structure Model of Methodical System Usage FitnessTechnology in Student Physical Education. International Journal of Applied Exercise Physiology, 9 (10), 89-96. 2020.

The Basic component of preschool education in Ukraine (new edition). Preschool education, 7, 17-18. 2012.

TKACHUK, T. The joy of knowledge. Preschool education, 9, 10-11. 2002.

ZEBZEEVA, V. L. On the forms and methods of environmental education of preschoolers. Preschool education, 7, 45-49. 1998.

ZHAMARDIY, V. O.; DONCHENKO, V. I.; YEMETS, A. V.; SKRINNIK, Y. O. Physical Development by Means of Fitness Technologies as One of General Aspects of Student's Health. Wiadomości Lekarskie. Tom LXXII, nr 5 cz II, 1074-1078. 2019.

ZHAMARDIY, V.; GRIBAN, G.; SHKOLA, O.; FOMENKO O.; KHRYSTENKO D.; DIKHTIARENKO Z.; YEROMENKO E.; LYTVYNENKO A.; TERENTIEVA N.; OTRAVENKO O.; SAMOKISH I.; HUSAREVYCH, O.; BLOSHCHYNSKYI, I. Methodical System of Using Fitness Technologies in Physical Education of Students. International Journal of Applied Exercise Physiology, 9 (5), 27-34. 2020.

ZHAMARDIY, V.; SHKOLA, O.; BEZPALIY, S.; KALYNOVSKYI, B.; VASYLENKO, O.; IVANOCHKO, I.; DOVGAN, N.; MALYNSKYI, I.; DANYLENKO, O.; GRIBAN, G.; PRONTENKO, K. Modern Fitness Technologies in the Physical Education of Students. Revista Dilemas Contemporáneos: Educación, Política y Valores. Año: VII, Número: Edición Especial, Artículo. 81. Período: Noviembre. 2019.

ZHAMARDIY, V.; SHKOLA, O.; BOICHENKO, A.; PRYSTYNSKYI, V.; KORNOSENKO, O.; DMYTRENKO, K.; KABATSKA, O.; STAROSELSKA, Y.; HORDIIENKO, O.; POSTOVA, S. Dynamics of Physical Fitness of Students during Powerlifting Classes. International Journal of Applied Exercise Physiology, 9(9), 49-60. 2020.

ZHAMARDIY, V. O.; SHKOLA, O. M.; OKHRIMENKO, I. M.; STRELCHENKO, O. G.; ALOSHYNA, A. I.; OPANASIUK, F. H.; GRIBAN, G. P.; YAHODZINSKYI, V. P.; MOZOLEV, O. M.; PRONTENKO, K. V. Checking of the Methodical System Efficiency of Fitness Technologies Application in Students' Physical Education. Wiadomości Lekarskie, Tom LXXIII, nr 2, 332-341. 2020.

ZHAMARDIY, V.; SHKOLA, O.; OTRAVENKO, O.; MOMOT, O.; ANDREIEVA, M.; ANDRIEIEVA, O.; MUDRYK, V.; SLUSAREV, V.; BROSLAVSKA, H.; PUTIATINA, G. Dynamics of the Functional State of Students in the Process of Powerlifting in Higher Education. International Journal of Applied Exercise Physiology, 9 (10), 24-35. 2020.

ZHAMARDIY, V.; SHKOLA, O.; TOLCHIEVA, H.; SAIENKO, V. Fitness Technologies in the System of Physical Qualities Development by Young Students. Journal of Physical Education and Sport, 20 (1), 142-149. 2020. 
ZHAMARDIY, V.; SHKOLA, O.; ULIANOVA, V.; BILOSTOTSKA, O.;

OKHRIMENKO, I.; OKHRIMENKO, S.; GRIBAN, G.; PRONTENKO, K.;

BLOSHCHYNSKYI, I. Influence of Fitness Technologies on the Student Youth's Physical Qualities Development. Revista Dilemas Contemporáneos: Educación, Política y Valores.

Año: VII, Número: Edición Especial, Artículo no: 49. Período: Octubre. 2019.

\section{How to reference this article}

KARAPUZOVA, I.; SULAIEVA, N.; MANZHELII, N.; VASHAK, O.; FAZAN, T. The development of preschoolers' cognitive and communicative activity in the process of educational and research activities in nature. Revista on line de Política e Gestão Educacional, Araraquara, v. 25, n. esp. 3, p. 1795-1809, Sep. 2021. e-ISSN: 1519-9029. DOI: https://doi.org/10.22633/rpge.v25iesp.3.15593

Submitted: $20 / 03 / 2021$

Required revisions: 05/06/2021

Approved: $12 / 07 / 2021$

Published: 01/08/2021 